STATE WORK 



\title{
STATE WORK
}

Public Administration and Mass Intellectuality

\author{
Stefano Harney
}

Duke University Press Durham and London 2002 
(C) 2002 Duke University Press

All rights reserved

Printed in the United States of America on acid-free paper

Typeset in Scala by Keystone Typesetting, Inc.

Library of Congress Cataloging-in-Publication Data appear on the last printed page of this book. 
This book is dedicated to

Carl Thorpe and Anne-Marie Stewart.

They taught me more about working in government, and more about justice and laughter,

than I could ever record. 
